\title{
ANCAMAN SPESIES INVASIF DI HUTAN PRODUKSI OINBIT KABUPATEN TIMOR TENGAH UTARA
}

\section{Willem Amu Blegur, Remigius Binsasi}

Fakultas Pertanian Universitas Timor, Indonesia

Email:willemblegur@unimor.ac.id, binsasiremigius@gmail.com

\begin{abstract}
Abstrak
Kajian vegetasi di kawasan hutan produksi Oinbit telah dilakukan untuk mengidentifikasi jenis yang tumbuh pasca tambang marmer. Akan tetapi, belum spesifik mempelajari adanya kehadiran dan kemelimpahan jenis yang berkarakter sebagai spesies invasif yaitu jenis yang hadir dari luar habitat dan mendominasi jenis yang ada. Aktivitas masyarakat di sekitar ada pula yang menebas dan membakar di sekitar hutan dengan skala kecil untuk pertanian. Masyarakat belum memahami adanya ancaman dalam pembakaran tidak ramah lingkungan tersebut. Tujuan penelitian ini adalah mempelajari distribusi dan kemelimpahan spesies dan potensi ancaman spesies invasif di hutan produksi Oinbit secara khusus pada semak Eupatorium adoratum dan Lantana camara. Pencuplikan data vegetasi dilakukan dengan metode kuadrat plot berukuran $20 \mathrm{~m}$ x 20 m sebanyak 5 ulangan. Peralatan dan bahan yang digunakan meliputi alat dan bahan standar untuk konstruksi kuadrat plot. Hasil yang diperoleh bahwa terdapat beberapa vegetasi yang menghuni di hutan Oinbit. Vegetasi tersebut mendapatkan ancaman adanya spesies invasive yaitu Eupatorium adorata dan Lantana camara sehingga berpotensi akan memengaruhi keberlanjutan spesies asli. Kehadiran spesies invasif ini pada awalnya dalam jumlah yang sedikit dan tersebar atau sparse. Akah tetapi oleh sebab kemampuan adaptasi yang tinggi dengan mekanisme r-selection maka baik Eupatorium odorata dan Lantana camara dengan nilai INP 198, 86 dan 18,25 yang memiliki potensi menjadi vegetasi yang mengkoloni habitat dan dapat dikategorikan sebagai spesies invasif pada ekosistem hutan produksi Oinbit. Penelitian di musim hujan menjadi penting untuk mempelajari pola dominasi kedua spesies semak tersebut.
\end{abstract}

Kata Kunci: spesies invasif; Eupatorium odorata; Lantana camara; Oinbit

\section{Abstract}

Study about type and growth form of vegetation in Hutan Produksi Oinbit after marble quarry has been done. There were no specific data for distribution and abundance of any invasive species. It could dominate in new area and disturb endemic type. People surround the forest doing their agriculture by small fire but if without environmentally friendly would impact degradation in ecosystem. The aims were to investigate the distribution and abundance of any species with the potential threat as invasive species in Hutan Produksi Oinbit espescially for shrub Eupatorium adoratum and Lantana camara. The collection of vegetation data is done by the plot square method measuring $20 \mathrm{~m} \times 20 \mathrm{~m}$ as much as 5 duplicates. The equipment and materials used include tools and standard materials for plot

$\begin{array}{ll}\text { How to cite: } & \text { Blegur, W, A., Binsasi, R., (2022) Ancaman Spesies Invasif Di Hutan Produksi Oinbit Kabupaten Timor } \\ & \text { Tengah Utara, Syntax Idea, 4(1), https://doi.org/ 10.36418/syntax-idea.v4i1.1739 } \\ \text { E-ISSN: } & \text { 2684-883X } \\ \text { Published by: } & \text { Ridwan Institute }\end{array}$


square construction. The results performed that vegetation is under threat from invasive species Eupatorium odorata and Lantana camara, potentially affecting the sustainability of native species. The presence of this invasive species is initially in small numbers and is scattered or sparse. But because of the high adaptability with the r-selection mechanism, both Eupatorium odorata and Lantana camara with INP values 198, 86 and 18.25 have the potential to become vegetation that colonizes habitats and can be categorized as invasive species in Oinbit-produced forest ecosystems. Data in rainy season for identification more about both species need to be done.

Keywords: invasive species; Eupatorium odorata; Lantana camara; Oinbit

\section{Received: 2021-12-22; Accepted: 2022-01-05; Published: 2022-01-20}

\section{Pendahuluan}

Hutan merupakan suatu ekosistem kompleks yang di dalamnya terjadi interaksi erat dan saling memengaruhi antar komponen biotik dan endemik. Hutan dalam bentangan landscape dari pesisir sampai pegunungan apabila dilestarikan akan memberikan manfaat ekologis dan ekonomis yang berkelanjutan (Herawati, 2016). Keanekaragaman hayati yang tinggi dapat ditemukan di hutan secara alamiah bahkan untuk endemic yang kering seperti endemik beriklim tropis semi arid atau dikenal sebagai dry land (Tarmizi \& Suwardji, 2018). Suatu kesatuan hutan dengan interaksi akan membentuk lingkungan yang hidup.

Lingkungan hidup merupakan kesatuan ruang dengan semua benda, daya, keadaan, dan makhluk hidup, termasuk manusia dan perilakunya, yang mempengaruhi alam itu sendiri, kelangsungan perikehidupan, dan kesejahteraan manusia serta makhluk hidup lain. Suatu lingkungan dapat dibedakan atas lingkungan hidup alami, lingkungan hidup buatan atau binaan dan lingkungan hidup sosial. Interaksi yang dinamis dan saling memengaruhi antara ketiga komponen yang erat akan mendukung keberlanjutan lingkungan tersebut (Effendi dkk., 2018) termasuk hutan.

Hutan Oinbit merupakan suatu endemik yang dihuni oleh berbagai komunitas biotik baik tumbuhan (vegetasi) dan hewan. Letak hutan Oinbit di daerah beriklim tropis semi arid yang sangat dipengaruhi oleh cahaya matahari, jumlah air dan pedosfer. Iklim yang meliputi cahaya matahari dan jumlah air baik air hujan atau air mata air menjadi factor pembatas kehadiran dan kemelimpahan biota dan berbagai interaksinya di daerah tropis semi arid baik interaksi positif untuk kehidupan dan juga sumber konflik atau degradasi lingkungan (Jocom dkk., 2016) (Suciantini, 2015) (Yanti \& Ibrahim, 2018). Tingkat evaporasi dan transpirasi bahkan evapotranspirasi sangat tinggi.

Pemanfaatan endemik hutan yang kurang ramah lingkungan berpotensi mengancan keakeragaman hayati dan malah merugikan manusia (Bria \& Binsasi, 2018). Aktivitas manusia seperti penebangan pohon, pembukaan lahan atau pembakaran sekilas memberikan manfaat bagi manusia. Akan tetapi, aktivitas tersebut akan menimbulkan terciptanya bukaan kanopi atau gap canopy. Selanjutnya gap canopy akan menjadi area yang paling mudah dikoloni oleh semak dan beberapa vegetasi lainnya 
yang mampu beradapatasi dengan faktor lingkungan saat terjadi terbukanya kanopi (Nurkhotimah dkk., 2017) (Purnomo dkk., 2018). Kehadiran semak akan semakin melimpah sebab mudah beradaptasi dengan unsur hara dan air yang sedikit. Semak memiliki tipe perkembangan $r$-selective.

Semak tersebut akan tumbuh melimpah dan menjadi spesies yang mengancam kehadiran vegetasi asli atau alami dari daerah tersebut. Semak tipe ini menjadi invasive species. Kehadiran spesies invasif baik di alam liar ataupun di ndemic hutan lindung sangat perlu dikelola bahkan diatasi dengan bijak (Blegur dkk., 2017) (Purnomo dkk., 2018). Beberapa contoh spesies invasif seperti Lantana camara dan Eupatorium adoratum, seperti yang telah disampaikan di atas, kemampuan adaptasi yang sangat baik terhadap tanah yang miskin unsur hara dan kurang air akan menjadi ancaman terhadap vegetasi asli. Selanjutnya dalam waktu yang endemik singkat dapat terjadi pergantian spesies (shifting species) dan mengganggu fungsi ekologis di ekosistem tersebut. Kondisi ini perlu penanganan yang baik dan bijaksana.

Kelestarian peranan hutan sering terusik atau terganggu (disturbance). Usikan yang dialami oleh hutan dapat dikategorikan sebagai usikan kecil sampai besar, usikan tidak tetap sampai simultan, dan usikan yang dapat diatasi oleh hutan tersebut ataupun tidak dapat diatasi (Yanti \& Ibrahim, 2018). Hal ini disebabkan hutan sebagai komunitas hidup. Seandainya usikan atau tekanan (stress) yang dialami juga akan direspon oleh hutan.

Manusia memiliki peranan secara langsung terhadap usikan atau tekanan yang dialami oleh hutan. Beberapa aktivitas manusia yang memicu adanya gangguan atau tekanan pada suatu ekosistem seperti penebangan hutan, pengambilan buah, pembukaan lahan dan /atau pembakaran. Contoh usikan yang disebutkan di atas, pasti menciptakan hutan yang terbuka dan tidak ada tutupan atau gap canopy. Kondisi gap canopy akan sangat rentan. Kerentanan yang dimaksudkan adalah bahwa area tersebut akan mudah dihuni oleh spesies atau komunitas yang seharusnya tidak boleh ada di area tersebut dan atau beberapa spesies tumbuhan lainnya yang mampu beradaptasi di bawah keterbukaan kanopi (Purnomo dkk., 2018).

Spesies invasfi merupakan spesies yang memiliki kecenderungan mengancam spesies asli yang ada di suatu area asli. Kehadiran dan kemelimpahan spesies invasif disebabkan kemampuan spesies ini untuk dapat beradaptasi dengan baik dan cepat terhadap kondisi habitat yang miskin hara dan air. Kemampuan tipe r-selective yang dimiliki sangat baik. Distribusi invasive species bahkan dapat melewati pembatas geografis dan batas negara. Telah teridentifikasi beberapa invasive species yang ada di Indonesia seperti Lantana camara, Eupatorium adoratum, Gliricidia sepium dan Leucaena leucocephala dan beberapa jenis pisces (Radiansyah, dkk., 2015), (Tjitrosoedirdjo dkk., 2017) (Nursanti \& Adriadi, 2018).

Pembakaran merupakan kebiasaan umum yang dilakukan oleh masyarakat di daerah kering atau dry land terutama untuk kegiatan penggembalaan ternak (Suek \& Randu, 2017). Keuntungan utama bahwa pembersihan dengan api atau pembakaran sangat mudah dan lebih cepat. Ada tiga tipe pembakaran yaitu pembakaran cepat, 
pembakaran dalam dan pembakaran mahkota. Pembakaran cepat atau splash burning memberikan manfaat daripada pembakaran ke dalam tanah dan pembakaran mahkota sampai pada merambat ke tumbuhan atau vegetasi yang ada di atas permukaan tanah. Akan tetapi pembakaran memiliki efek yang perlu disikapi dan dilakukan dengan bijak sebab akan memberikan manfaat positif dan sebaliknya dampak negatif (Firmansyah, 2012). Seperti dijelaskan sebelumnya, saat pembukaan lahan termasuk dengan pembakaran maka akan tercipta gap canopy yang akan menjadi area koloni semak endemi.

Hutan Oinbit sebagai hutan alam yang dapat menjadi sumber plasma nutfah dan memiliki peranan ekologis dan ekonomis telah terpapar oleh kehadiran beberapa invasive species. Belum pernah dilakukan penelitian untuk mencacah spesies dan dominasi semak yang berpotensi sebagai invasive species di Hutan Oinbit. Selain itu belum dikaji peranan manusia untuk menjaga Hutan Oinbit dari serangan semak endemi dan endemi-faktor lingkungan lainnya yang mendukung distribusi dan kemelimpahan semak endemic tersebut. Pemahaman dan penanganan yang lebih dini akan menjaga fungsi ekologis dan ekonomis Hutan Oinbit secara berkelanjutan sehingga dapat terwujud lingkungan yang lestari. Hutan produksi Oinbit merupakan hutan ada di desa Oinbit dan berada di bukit Oinbit. Pada sekitar bagian puncak bukit Oinbit pernah dimanfaatkan oleh salah satu industri untuk mengambil batu marmer dan di bagian kaki bukit dimanfaatkan oleh penduduk lokal untuk pertanian dengan hasil yang dikonsumsi skala rumah tangga.

Kajian tentang vegetasi di kawasan hutan produksi Oinbit telah dilakukan untuk mempelajari jenis vegetasi khususnya yang hadir dan melimpah pasca adanya usaha tambang marmer. Akan tetapi, kajian tersebut hanya berupa idenfikasi jenis dan jumlah vegetasi yang ada di kawasan tersebut dan belum mengkaji adanya ancaman kehadiran dan kemelimpahan spesies invasif. Oleh sebab itu, tujuan penelitian ini untuk mempelajari tipe growth form yang ada di hutan produksi Oinbit meliputi pohon, sapling, semak, rumput dan lian dan mempelajari secara spesifik mempelajari adanya potensi ancaman dari semak Lantana camara dan Eupatorium adoratum di hutan produksi Oinbit. Kajian ini memberikan manfaat bahwa masyarakat di sekitar hutan produksi Oinbit dan masyarakat umum dapat mempelajari adanya kehadiran semak $L$. camara dan E. adoratum yang mengkoloni dan memiliki potensi besar sebagai spesies invasif di hutan produksi Oinbit. Selanjutnya masyarakat lebih ramah lingkungan dalam aktivitas pertanian dan perkebunan dalam hal menebas dan membakar di kawasan tersebut.

\section{Metode Penelitian}

Penelitian ini akan dilaksanakan pada bulan Mei sampai dengan bulan Oktober tahun 2021 di Hutan Produksi Oinbit Kabupaten Timor Tengah Utara untuk mencuplik data vegetasi. Penelitian ini menggunakan pendekatan ekologis deskriptif kuantitatif dan kualitatif. Pendekatan deskriptif kuantitatif untuk menganalisis distribusi dan kemelimpahan vegetasi khususnya endemi spesies dan endemik. Untuk mencuplik data 
vegetasi di hutan lindung Oinbit dilakukan dengan mempersiapkan peralatan untuk konstruksi plot kuadrat berukuran $20 \mathrm{~m}$ x 20 m yang meliputi tali tampar, tiang tonggak, tiang pancang, buku data dan pena.

Pencuplikan data vegetasi pada growth form pohon, sapling, semak, rumput dan liana pada kuadrat plot berukuran $20 \mathrm{~m}$ x $20 \mathrm{~m}$ dengan ulangan sebanyak 5 kali atau 5 plot sehingga total luasannya adalah $2000 \mathrm{~m}^{2}$ Pencuplikan data pada spot dengan kerapatan vegetasi tinggi di hutan produksi Oinbit, secara khususnya pada spot yang didominasi oleh spesies invasif. Data vegetasi akan dianalisis sampai menentukan indeks nilai penting (INP). Hasil akan dipaparkan secara deskriptif kuantitatif dan kualitatif. Selanjutnya mempelajari dampak kehadiran dan kemelimpahan spesies invasif terhadap vegetasi asli di Hutan Produksi Oinbit.

\section{Hasil dan Pembahasan}

\section{Vegetasi di Hutan Oinbit}

Vegetasi sebagai kumpulan komunitas tumbuhan yang menempati suatu area pada suatu waktu. Variasi vegetasi yang lebih tinggi ditemukan pada hutan. Variasi tersebut baik jenis dan jumlah yang ada serta kondisi hutan tersebut. Hutan yang sehat direpresentasikan oleh tingginya tingkat variasi jenis sebab setiap jenis memiliki peran dalam hutan tersebut. Diskusi tentang hutan yang sehat dengan kondisi vegetasi yang ada di dalamnya pasti sangat erat terkait dengan kajian tentang distribusi dan kemelimpahan serta adanya peranan manusia. Jumlah vegetasi yang melimpah dan terdistribusi di hutan sangat penting bagi keberlanjutan hutan tersebut. Walaupun demikian, kemelimpahan dan distribusi vegetasi dalam hutan juga merespon endemi lingkungan yang ada (Blegur dkk., 2017) (Bria \& Binsasi, 2018).

Hutan Oinbit merupakan salah satu hutan yang ada di daerah Onbit yang masuk dalam Kabupaten Timor Tengah Utara. Hutan ini ada di lingkungan dengan iklim tropis kering. Jumlah hujan yang terbatas dan kondisi tanah yang kritis direspon oleh vegetasi yang ada di hutan ini. Vegetasi evergreen menempati punggung sampai di puncak gunung karst di Oinbit. Vegetasi desiduos berhabitat di kaki gunung karst ini. Suksesi sekunder telah terjadi di kaki hutan Oinbit yang ditandai dengan keliling pohon yang tidak terlalu besar. Semua vegetasi di kaki gunung ini memiliki kemampuan bertahan hidup dan melestarikan jenis untuk waktu yang lama. Selanjutnya semua vegetasi tersebut memiliki peranan yang mendukung antar komunitas dalam hutan dan juga mendukung aktivitas manusia. Adanya aktivitas manusia sangat memengaruhi keberlanjutan vegetasi di hutan Oinbit. Bahkan muncul ancaman adanya spesies alien atau spesies invasive yang pasti akan mengancam keberlangsungan jumlah jenis dan jumlah individu di hutan Oinbit. 


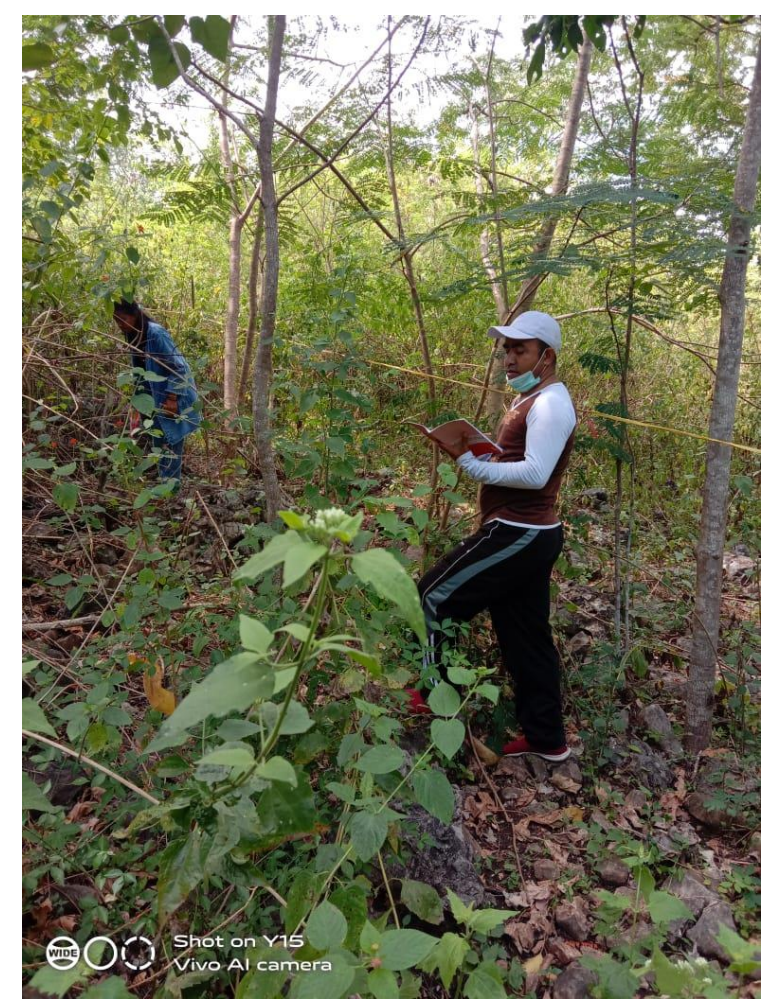

\section{Gambar 1}

Data Vegetasi Lokasi 2 (dok. pribadi)

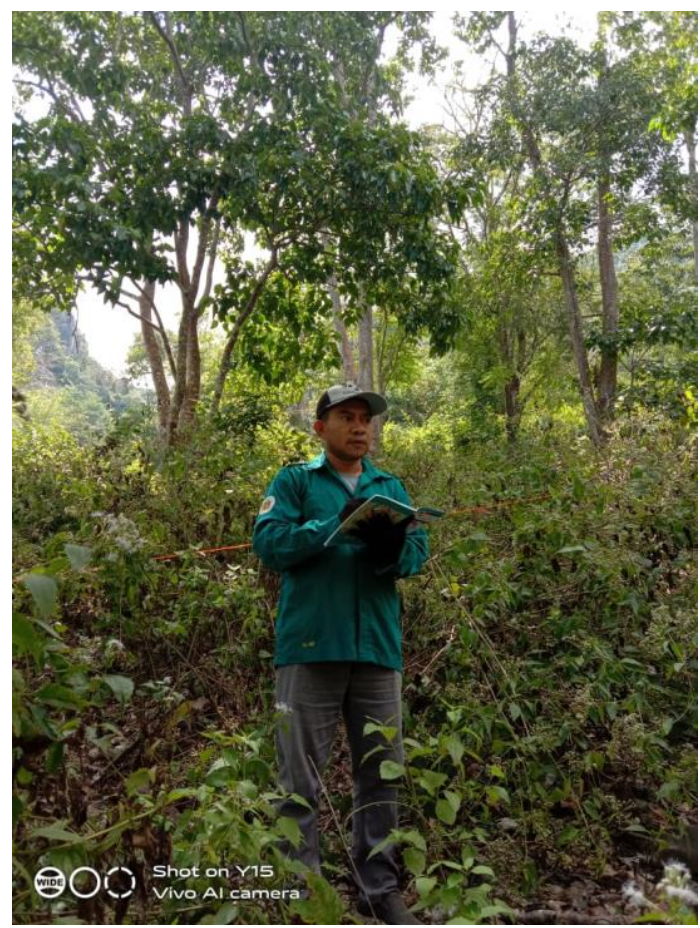

\section{Gambar 2}

Data Vegetasi Lokasi 3 (dok. pribadi) 


\section{Peranan Jenis Tumbuhan dalam Hutan Oinbit dan Nilai INP}

Secara umum, tumbuhan memiliki banyak peranan seperti mensuplai oksigen, peneduh, pelindung, estetika yang disesuaikan dengan morfologi dan fisiologi jenis tumbuhan tersebut. Jenis yang ada dalam hutan dapat dikategorikan ke dalam bentuk tumbuh atau growthform antara lain pohon, sapling, seedling, semak, rumput, liana, paku-pakuan. Lalu, seperti yang telah dipaparkan sebelumnya bahwa setiap jenis tumbuhan yang endemi komunitas dalam hutan Oinbit memiliki peranan masingmasing atau niche. Peranan penting suatu jenis tumbuhan dalam komunitasnya dapat dipelajari melalui pendekatan Indeks Nilai Penting atau INP.

Nilai INP diperoleh dari nilai frekuensi endemi, densitas endemi, luas basal area endemi dan luas kanopi endemi sebagai hasil perhitungan suatu jenis tumbuhan. Semakin tinggi nilai INP yang dimiliki oleh suatu jenis maka spesies tersebut menjadi penting. Adanya usikan atau gangguan akan menimbulkan respon vegetasi yang dimulai dengan adanya penurunan jumlah jenis, penurunan jumlah individu sampai terjadinya degradasi tumbuhan. Tabel 1 dan 2 menampilkan nilai INP yang ada berdasarkan beberapa growthform yang ditemukan di hutan Oinbit.

Tabel 1

INP Growthform Pohon

\begin{tabular}{rlr}
\hline \multicolumn{2}{l}{ Pohon-Sapling } & (/2000m2) \\
\hline & No & \\
\hline 1 & Aleurites moluccanus & 56,30269124 \\
\hline 2 & Gmelina arborea & 18,25087796 \\
\hline 3 & Ziziphus mauritiana Lam. & 7,013711499 \\
\hline 4 & Albizia chinensis & 6,636283719 \\
\hline 5 & Schleichera oleosa & 6,353264345 \\
\hline 6 & Tectona grandis & 4,47729316 \\
\hline 7 & Tamarindus indica & 4,328919049 \\
\hline 8 & Celtis australis & 4,293345908 \\
\hline 9 & Hautuamani & 3,648605259 \\
\hline 10 & Vachellia leucophloea & 3,648605259 \\
\hline 11 & Habiscus tiliaceus & 3,126279198 \\
\hline 12 & Agathis dammmara & 2,930731244 \\
\hline 13 & Tilia sp & 2,823784914 \\
\hline 14 & Psidium guajava & 2,751334442 \\
\hline 15 & Haupena & 2,496102091 \\
\hline 16 & Acer laurinum & 2,41346326 \\
\hline 17 & Daun mirip kemiri & 2,221966662 \\
\hline 18 & Quercus argentata & 2,08498889 \\
\hline 19 & Juglans regia L & 2,076745559 \\
\hline 20 & Daun mirip Gamal & 2,075013137 \\
\hline 21 & Daun mirip Mangga & 2,069145354 \\
\hline 22 & Daun mirip Nangka & 2,067853058 \\
\hline & &
\end{tabular}




\begin{tabular}{clr}
\hline Pohon-Sapling & $(\mathbf{/ 2 0 0 0 m 2 )}$ \\
\hline & Nama Spesies & \\
\hline No & & \\
\hline 23 & Daun mirip coklat & 2,064984947 \\
\hline 25 & Morinda citrifolia & 2,057616132 \\
\hline 26 & Berdaun mirip cermelek & 2,056574979 \\
\hline 27 & Haukislase & 1,917617797 \\
\hline 28 & Ficus septica & 1,874408191 \\
\hline 29 & Daun mirip pates & 1,870924968 \\
\hline 30 & Daun mirip kopi & 1,865685535 \\
\hline 31 & Daun mirip kusambi & 1,865343415 \\
\hline 32 & Daun hijau buat katapel & 1,865009601 \\
\hline 33 & Pohon duri & 1,864378756 \\
\hline 34 & Daun mirip Kedondong & 1,86428963 \\
\hline 35 & Alstonia scholaris & 1,864187912 \\
\hline 36 & Kabu & 1,863561287 \\
\hline & &
\end{tabular}

Tabel 2

Nilai INP Growthform Semak, Rumput dan Liana

\begin{tabular}{|c|c|c|}
\hline \multicolumn{2}{|l|}{ Semak } & \multirow[t]{2}{*}{$(/ 2000 \mathrm{~m} 2)$} \\
\hline No & Nama Spesies & \\
\hline 4 & Eupatorium odorata & 198,863422 \\
\hline 5 & Lantana camara & 18,25333642 \\
\hline 1 & Alchornea cordifilia & 1,895963811 \\
\hline 3 & Euonymus fortunei & 1,875330512 \\
\hline 6 & Ligustrum vulgure & 1,874177817 \\
\hline 2 & Capsicum frutescens & 1,864968281 \\
\hline \multicolumn{3}{|l|}{ Rumput } \\
\hline No & Nama Spesies & \\
\hline 1 & Tridax Procumbens & 2,651739099 \\
\hline \multicolumn{3}{|l|}{ Liana } \\
\hline No & Nama Spesies & \\
\hline 1 & Uvaria rufa & 1,871397501 \\
\hline
\end{tabular}

\section{Ancaman Spesies Invasif di Hutan Oinbit}

Spesies endemi merupakan spesies non endemi yang hadir dan biasanya mengkoloni bahkan dapat mengubah jumlah dan jenis spesies endemi atau shifting species pada suatu habitat. Kehadiran dan kemelimpahan spesies invasf disebabkan kemampuan adaptasi yang tinggi pada habitat baru tersebut. Mereka memiliki tipe perkembangan hidup r-type yakni mampu melakukan dormansi secara baik dan saat reproduksi akan menghasilkan benih atau biji dalam jumlah banyak dan telah melakukan adaptasi terhadap lingkungan secara alamiah atau campur tangan manusia (Ariyanto dkk., 2014) (Gunawan dkk., 2011). Salah satu pendukung distribusi dan 
kemelimpahan spesies endemi yakni adanya perubahan atau usikan pada suatu habitat seperti pembakaran, penebangan pohon atau penggunaan bahan pestisida secara berlebihan (Firmansyah, 2012).

Hutan produksi merupakan suatu kawasan hutan yang digunakan sebagai hutan produksi untuk memenuhi keperluan masyarakat pada umumnya dan khususnya untuk pembangunan, endemik dan ekspor. Tipe hutan ini biasanya berawal dari hutan alami yang dikonversi wilayahnya untuk diambil sumber daya tertentu yang ada di dalamnya. Selain itu, ada pula tipe hutan produksi yang berasal dari lahan yang sengaja dibuat menjadi hutan untuk tujuan menjadi hutan produksi. Hutan produksi menjadi suatu ekosistem yang rentan terjadi perubahan baik secara biotik yaitu flora, fauna bahkan mikrobia yang ada di dalamnya dan juga perubahan fisika dan kimia meliputi kandungan hara tanah, udara di endemi tersebut sampai jumlah dan kualitas air yang mungkin ada di dalamnya. Faktor manusia atau antropogenik di sekitar hutan dan /atau di luar wilayah hutan yang mengambil sumber daya hutan pun akan memengaruhi keberlanjutan fungsi hutan produksi tersebut.

Hutan produksi Oinbit juga mengalami kondisi seperti tersebut di atas. Isu lama tentang perubahan ekosistem hutan produksi Onbit oleh sebab adanya aktivitas penambangan batu marmer dan sudah berhenti. Isu lainnya adalah aktivitas pertanian dan perkebunan warga yang bersifat sementara. Kedua isu menjadi penting secara antropogenik bagi perubahan vegetasi yang ada di dalam hutan produksi Onbit. Pembukaan lahan baik untuk penambangan marmer dan hutan aktivitas pertanian dan perkebunan yang dilakukan telah memicu kehadiran dan kemelimpahan spesies invasive yaitu Eupatorium odorata dan Lantana camara yang memiliki nilai INP 198,86 dan 12, 25. Kedua semak ini mengembangkan kemampuan tipe r yang dormansi pada musim kering tapi sudah memencarkan biji atau benih yang siap untuk tumbuh. Pada musim hujan, benih keduanya akan segera tumbuh dengan cepat memanfaatkan tanah yang miskin hara dan segera siap untuk reproduksi bagi keberlanjutannya. Jika hal ini dibiarkan secara terus menerus maka hutan produksi Oinbit akan mendapatkan ancaman sangat tinggi akan terjadi pergantian spesies endemi atau shifting species dan akan mengubah fungsi ekologis di hutan produksi Oinbit. 


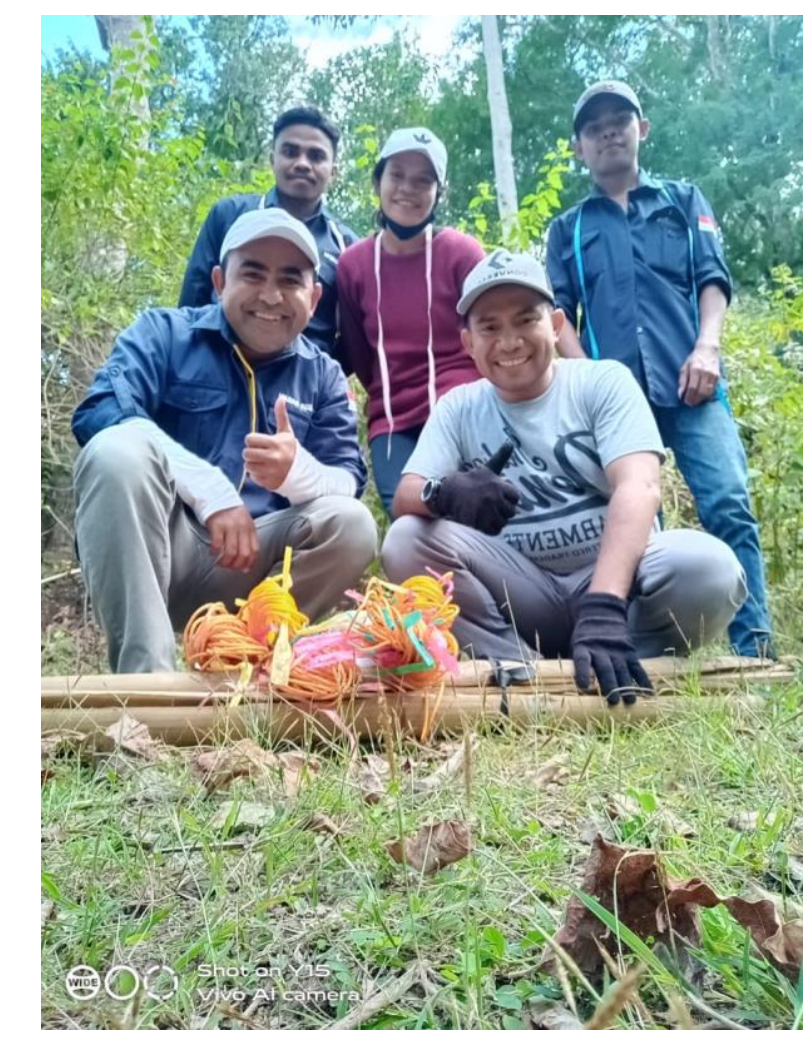

\section{Gambar 3 \\ Tim Pengambilan Data Vegetasi (dok. pribadi)}

\section{Kesimpulan}

Hutan dengan komunitas asli di hutan produksi Oinbit mendapat ancaman dari spesies invasif yaitu semak Eupatorium odorata dan Lantana camara dengan nilai INP 198, 86 dan 18,25. Selain itu, untuk vegetasi asli yang perlu dijaga antara lain Aleurites mollucanus dan Gmelia arborea dengan nilai INP 56,30 dan 18,25. Banyak juga vegetasi asli lainnya yang terhambat pertumbuhan baik seedling dan sapling oleh kedua spesies invasive tersebut di atas. Penelitian ini perlu dilakukan juga pada musim penghujan untuk mendapatkan data pembanding kehadiran dan kemelimpahan vegetasi terutama yang berpotensi sebagai spesies invasif. 


\section{BIBLIOGRAFI}

Ade Adriadi, Dan Nursanti, Nusanti. (2018). Keanekaragaman Tumbuhan Invasif di Kawasan Taman Hutan Raya Sultan Thaha Saifuddin, Jambi. 23(1), 85-91.Google Scholar

Ariyanto, Joko, Widoretno, Sri, Nurmiyati, Nurmiyati, \& Agustina, Putri. (2014). Bentuk Kehidupan (Life Form) Tumbuhan Penyusun Vegetasi Di Kotamadya Surakarta. Bioedukasi: Jurnal Pendidikan Biologi, 7(2), 10-17. Google Scholar

Bidang, Deputi, Kerusakan, Pengendalian, Dan, Lingkungan, Iklim, Perubahan, Lingkungan, Kementerian, \& Dan, Hidup. (2015). Strategi Nasional dan Arahan Rencana Aksi Pengelolaan Jenis Asing Invasif di Indonesia. Retrieved from https://docplayer.info/35732542-Strategi-nasional-dan-arahan-rencana-aksi pengelolaan-jenis-asing-invasif-di-indonesia.html.

Blegur, Willem Amu, Djohan, Tjut Sugandawaty, \& Ritohardoyo, Su. (2017). Vegetasi Habitat Komodo dalam Bentang Alam Riung dan Pulau Ontoloe di Nusa Tenggara Timur. Majalah Geografi Indonesia, 31(1), 95-111. Google Scholar

Bria, Emilia Juliyanti, \& Binsasi, Remigius. (2018). Kajian Vegetasi Kawasan Pasca Tambang Marmer di Kabupaten Timor Tengah Utara. Saintekbu, 10(2), 10-16. Google Scholar

Effendi, Rahayu, Salsabila, Hana, \& Malik, Abdul. (2018). Pemahaman Tentang Lingkungan Berkelanjutan. Modul, 18(2), 75-82. Google Scholar

Firmansyah, M. Anang dan Subowo. (2012). Dampak Kebakaran Lahan Terhadap Kesuburan Fisik, Kimia, dan Biologi Tanah serta Alternatif Penanggulangan dan Pemanfaatannya. 6(2), 89-100. Retrieved from http://ejurnal.litbang.pertanian.go.id/index.php/jsl/article/view/6393/5696. Google Scholar

Gunawan, Wawan, Basuni, Sambas, Indrawan, Andry, Prasetyo, Lilik Budi, \& Soedjito, Herwasono. (2011). Kawasan Hutan Taman Nasional Gunung Gede Pangrango. Jurnal Pengelolaan Sumberdaya Alam Dan Lingkungan, 1(2), 93-105. Google Scholar

Herawati, Elisabeth Ika. (2016). Kajian Ekologi dan Ekonomi Pemanfaatan Hutan Mangrove di Desa Pangkalan Siata Kecamatan Pangkalan Susu Kabupaten Langkat (Universitas Sumatra Utara). Retrieved from https://repositori.usu.ac.id/bitstream/handle/123456789/1217/147004016.pdf?sequ ence $=1 \&$ isAllowed=y. Google Scholar

Jocom, Hary, D Kameo, Daniel, Utami, Intiyas, \& Kristijanto, A. Ign. (2016). Air dan Konflik: Studi Kasus Kabupaten Timor Tengah Selatan. Jurnal Ilmu Lingkungan, 14(1), 51-61. Google Scholar 
Nurkhotimah, Hikmat, Agus, \& Setyawati, Titiek. (2017). Komposisi, Struktur dan Keanekaragaman Spesies Tumbuhan di Cagar Alam Dungus Iwul, Kabupaten Bogor. Media Konservasi, 22(2), 138-145. Google Scholar

Purnomo, Danang Wahyu, Usmadi, Didi, \& Hadiah, Julisasi Tri. (2018). Dampak Keterbukaan Tajuk terhadap Kelimpahan Tumbuhan Bawah pada Tegakan Pinus oocarpa Schiede dan Agathis alba (Lam) Foxw. Jurnal Ilmu Kehutanan, 12(1), 6173. Google Scholar

Suciantini, Suciantini. (2015). Interaksi iklim (curah hujan) terhadap produksi tanaman pangan di Kabupaten Pacitan. 1(April), 358-365.

Suek, Ferdinan. (2010). Hubungan Pembakaran Dengan Padang Penggembalaan Dan Aktivitas Pertanian Di Nusa Tenggara Timur. Partner, 17(1), 78-86. Retrieved from https://media.neliti.com/media/publications/159904-ID-hubunganpembakaran-dengan-padang-pengge.pdf. Google Scholar

Tarmizi, T., \& Suwardji, S. (2018). Keaneka Ragaman Hayati Pada Wilayah Lahan Kering. Retrieved from http://eprints.unram.ac.id/id/eprint/1715\%0A. Google Scholar

Tjitrosoedirdjo, Soekisman. (2017). Pedoman Analisis Risiko Tumbuhan Asing Invasif (Post Border). In FORIS Indonesia (Vol. 110). Retrieved from https://balaikliringkehati.menlhk.go.id/wp-content/uploads/Post-Border-RiskAalysis-Book.pdf.

Yanti, Rinda, \& Ibrahim, Hasan. (2018). Kajian Sosiologi Perilaku Konservasi dengan Wanatani Wilayah Semi Arid Khatulistiwa (Studi Kasus: di Kecamatan Amarasi, NTT). Journal of Applied Agricultural Science and Technology, 2(2), 55-71. Google Scholar

\section{Copyright holder:}

Willem Amu Blegur, Remigius Binsasi (2021)

\section{First publication right:}

Syntax Idea

This article is licensed under:

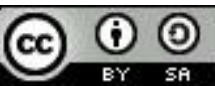

